\title{
DLACZEGO INWESTORZY POPEŁNIAJĄ BŁĘDY? NEUROEKONOMIA - CZYLI O TYM, JAK NEUROBIOLOGIA MOŻE POMÓC PRAWNIKOM
}

\author{
WHY DO CONSUMERS MAKE MISTAKES? NEUROECONOMICS \\ AND HOW IT MIGHT IMPROVE FINANCIAL REGULATION
}

\begin{abstract}
Streszczenie: Konsumenci aktywni na rynku przejawiają tendencję do popełniania błędów o podłożu behawioralnym, którymi obarczony jest niemal każdy proces podejmowania decyzji. Dzięki połączeniu obserwacji psychologicznych i teorii ekonomicznych z postępem w dziedzinie neurobiologii nowa gałąź nauki określana mianem neuroekonomii dostarczyła wiedzy o mechanizmach działania ludzkiego mózgu na etapie podejmowania decyzji inwestycyjnych. Znajdując biologiczne uzasadnienie dla najczęściej popełnianych przez konsumentów błędów - dążenia do natychmiastowej gratyfikacji oraz uzależnienia od punktu odniesienia - prawodawca uzyskał zupełnie nową wiedzę o funkcjonowaniu rynku. Powstaje pytanie, czy jest możliwe wykorzystanie tej wiedzy w perspektywie regulacyjnej.
\end{abstract}

Słowa kluczowe: neuroekomia; błędy behawioralne; efekt posiadania; natychmiastowa gratyfikacja; dyskontowanie hiperboliczne

Received: 07.2018

\begin{abstract}
Consumers' decision-making process is proved to be prone to behavioural biases. Due to interesting psychological findings combined with understanding of economic theories and recent development in the area of neuroscience, a new interdisciplinary field has emerged - neuroeconomics. Research conducted on human brain improved our understanding of cognitive and biological foundations of making investment decisions. Being able to explain mechanisms of two major behavioural biases, namely instantaneous gratification and reference dependence, indirectly provide the unique knowledge about financial markets. The question, however, arises: would lawyers use that knowledge while thinking about changing financial regulation?.
\end{abstract}

Key words: neuroeconomics; behavioural biases; endowment effect; instantaneous gratification; hyperbolic discounting.

Accepted: 09.2018

* Wydział Prawa i Administracji Uniwersytet Jagielloński 


\section{Wstęp i cel pracy}

Celem niniejszej pracy jest identyfikacja tych błędów popełnianych przez jednostki, które najsilniej wpływają na podejmowane decyzje przy zawieraniu transakcji na rynkach finansowych, a następnie naukowa próba zrozumienia ich podłoża. Koniecznym staje się przy tym zebranie dotychczas wypracowanych wniosków dotyczących procesu podejmowania decyzji zarówno w aspekcie psychologicznym, jak i stricte biologicznym. Dopiero dogłębne zrozumienie mechanizmów odpowiedzialnych za pozornie irracjonalne zachowania konsumentów oraz zaakceptowanie nieuchronności ich występowania pozwoli prawodawcy na dobranie najbardziej skutecznych środków regulacyjnych, które nakierowane zostaną na realne problemy, z którymi zmaga się uczestnik rynku, bez nadmiernej ingerencji prawnej ograniczającej wolność gospodarczą.

Pojawienie się konsumentów na rynkach finansowych oraz ich rosnący udział w budowie wzrostu gospodarczego powodują, że regulatorzy nie mogą dłużej pozostawać obojętni na konkretne potrzeby tej właśnie grupy. Główną motywacją każdej jednostki do inwestowania jest pespektywa zysku; jednakże, gdy w zestawieniu z zagrożeniami, jakie niesie rynek, okaże się, że obawy przewyższają korzyści, nieuchronnym stanie się proces odpływu inwestorów detalicznych z rynku. Wyzwaniem dla prawodawcy jest więc stworzenie takich uwarunkowań i okoliczności, aby konsumenci byli w stanie dokonywać inwestycji w poczuciu zabezpieczenia ich interesów w jak najwyższym stopniu, co potencjalnie może uchronić ich przed popełnianiem błędów skutkujących w konsekwencji efektem ucieczki z rynku.

\section{Konsumenci na rynkach - identyfikacja problemów}

Identyfikacja i zrozumienie problemów związanych z aktywnością inwestorów detalicznych na rynkach od lat pozostaje jednym z głównych wyzwań prawnych. W przeciągu ostatnich lat wielu odpowiedzi w tym zakresie dostarczyła innowacyjna gałąź nauki określana mianem neuroekonomii (neuroeconomics). Połączenie wysiłków ekonomistów, psychologów oraz neurobiologów pozwoliło na rozkwit tej unikatowej dyscypliny, która jako naczelny 
cel stawia sobie wypracowanie generalnej, zunifikowanej teorii wyjaśniającej zasady rządzące ludzkim zachowaniem. W tym swoistym konglomeracie nauk ekonomiści i psychologowie odpowiadają za obserwację i zrozumienie określonych modeli oraz tendencji w ludzkim postępowaniu; rola neurobiologów sprowadza się natomiast do dostarczania narzędzi naukowych pozwalających na wyjaśnienie mechanizmów biologicznych odpowiadających za tak zidentyfikowane zachowania [Glimcher, Rustichini 2004, 447-448].

Jednym z największych sukcesów osiągniętych w dziedzinie neuroekonomii okazały się badania nad procesami zachodzącymi w ludzkim mózgu przy procesie podejmowania decyzji przez inwestorów. W pierwszej kolejności doświadczenia empiryczne i wnikliwe obserwacje poczynione przez psychologów ujawniły, że co do zasady proces podejmowania decyzji każdorazowo obarczony jest tzw. błędami o podłożu behawioralnym (behavioralbiases). Dziś wiadomo już, że stanowią one drugie obok asymetrii informacyjnej główne zagrożenie dla konsumentów na rynkach. Wnikliwa obserwacja ludzkiego zachowania pozwoliła na zidentyfikowanie określonych skłonności, dzięki czemu możliwe stało się wyróżnienie podstawowych typów tego rodzaju błędów. Następnym krokiem stała się próba odpowiedzi na pytanie, czy istnieją mechanizmy i procesy o podłożu biologicznym, które mogą leżeć u podstaw popełnianych przez decydentów tendencyjnych błędów, a jeśli tak, to czy neurobiologia jest w stanie naukowo je wytłumaczyć. W ten sposób zrozumielibyśmy kognitywne podstawy dla procesu podejmowania decyzji.

Spośród wielu zidentyfikowanych dotychczas tendencyjnych zachowań ludzkich istnieją dwa podstawowe błędy behawioralne, które są najbardziej przydatne dla zrozumienia procesu podejmowania decyzji przez uczestników rynku finansowego. Dokonując tłumaczenia w tym zakresie terminologii angielskiej, można określić je mianem: (1) dążenia do natychmiastowej gratyfikacji (instantaneousgratification) [Harris, Laibson 2013, 205] oraz (2) uzależnienia od punktu odniesienia (referencedependence). Ich podstawowe założenia wraz z implikacjami dla konsumentów dokonujących inwestycji na rynkach zostaną kolejno przedstawione poniżej. 


\section{Dążenie do natychmiastowej gratyfikacji (InstantaneousGratification)}

Obserwacja ludzkiego zachowania w procesie podejmowania decyzji doprowadziła do wypracowania zaskakujących spostrzeżeń odnoszących się do sposobu, w jaki jednostki wartościują dobra, które są w stanie pozyskać w określonych odstępach czasowych. Okazało się bowiem, że mamy tendencję do przypisywania innej wartości poszczególnym dobrom w zależności od tego, czy jedną z dostępnych opcji jest możliwość pozyskania go ze skutkiem natychmiastowym.

Zgodnie z tezami wypracowanymi w podstawowych teoriach ekonomicznych spadek wartości dóbr w oczach jednostki (czyli swoisty „czynnik dyskontowy") powinien mieć charakter stały. Typowy racjonalny homo economicus kieruje się więc stałym czynnikiem dyskontowym niezależnie od tego, jakie dwa punkty na osi czasu będzie ze sobą porównywać [Lo 2017, 98].

W rzeczywistości okazuje się jednak, że ów stały spadek wartości zaburzony zostaje poprzez dążenie człowieka do natychmiastowego uzyskania nagrody pomimo że jest ona mniejsza niż zysk możliwy do osiągnięcia w niedalekiej nawet przyszłości. Przykładowo oznacza to, że jeżeli mamy do wyboru zwrot w postaci 100 zł $(x=100)$ w tym momencie $(t=0)$, to większość osób uzna tę opcję za korzystniejszą niż zwrot w wysokości 130 zł ( $x=130)$ w odstępie tygodniowym $(t=1)$. Wypracowany na tej podstawie czynnik dyskontowy (discountrate) nie znajduje jednak bezpośredniego przełożenia na sytuację, gdy do wyboru mamy dwa dobra, z których obu możemy oczekiwać dopiero w przyszłości. Kontynuując powołany przykład, okazuje się, że zupełnie odmienne będzie ludzkie zachowanie, gdy stanie się przed wyborem pomiędzy otrzymaniem 130 zł w odstępie tygodniowym $(x=130, t=1)$, a 160 zł w odstępie dwutygodniowym ( $x=160, t=3)$ - nie zajdzie tu aż tak dobitna przewaga dla opcji pierwszej. Reasumując, stwierdzić należy, że wartościowanie pozostaje w znacznej mierze zależne od punktów porównawczych umiejscowionych w czasie, a ludzie przy podejmowaniu decyzji wcale nie kierują się jednakowym czynnikiem dyskontowym. Zjawisko to określane jest mianem "dyskontowania hiperbolicznego" (hyperbolicdiscounting) [Laibson 1997, 443]. 
Pomimo że teza o hiperbolicznym dyskontowaniu stoi w sprzeczności z teoriami ekonomicznymi, co ciekawe, jest ona w pełni koherentna z wynikami badań nad aktywnością ludzkiego mózgu przeprowadzonych przez neurobiologów. Jednym z najbardziej przełomowych w tej dziedzinie okazały się eksperymenty przeprowadzone przez McClure et al., w ramach których grupa naukowców zdołała potwierdzić, że w ludzkim mózgu istnieją w rzeczywistości dwa odrębne systemy odpowiedzialne za proces podejmowania decyzji, które zaczęto określać mianem systemu $\beta$ oraz systemu $\delta$. Pierwszy z nich powiązany został z aktywnością układu limbicznego mózgu, drugi natomiast z procesami biologicznymi zachodzącymi w korze przedczołowej i płacie ciemieniowym, co do których powszechnie uważa się, że są to obszary odpowiedzialne za podejmowanie przemyślanych działań (np. za planowanie w perspektywie długoterminowej). Posługując się techniką neuroobrazowania, naukowcy zdołali zidentyfikować obszary w ludzkim mózgu zaangażowane w proces wyboru pomiędzy różnymi opcjami odroczonymi w czasie (intertemporal choice). Fundamentalnym wnioskiem płynącym z przeprowadzonych badań było stwierdzenie, iż układ limbiczny wykazuje szczególnie wzmożoną aktywność w przypadku, gdy jedna z oferowanych opcji niesie za sobą możliwość uzyskania wynagrodzenia w trybie natychmiastowym, podczas gdy obszary mózgu należące do tzw. systemu $\delta$ nie wykazały analogicznej podatności, a poziom ich aktywności pozostał stały w każdym wypadku, gdy w grę wchodziła konieczność podjęcia decyzji. Powyższe dowodzi, że określone partie mózgu wykazują zintensyfikowaną aktywność, gdy w perspektywie pojawia się możliwość uzyskania natychmiastowej gratyfikacji. Wypracowane wnioski są więc spójne z tym, co wykazały obserwacje psychologiczne, wobec czego stanowią swoiste naukowe wytłumaczenie dla jednego z podstawowych typów błędów popełnianych przez uczestników rynku.

\section{Uzależnienie od punktu odniesienia (Reference Dependence)}

Według podstawowych założeń nauk ekonomicznych proces dokonywania wyboru pomiędzy różnymi opcjami o wymiernych korzyściach finansowych powinien opierać się na mechanizmie polegającym na analizie obiektywnych danych udostępnionych decydentowi, a następczo na prostym 
przeniesieniu wyników tej analizy na wybór konkretnej opcji, która wydaje się być najlepiej dostosowana do aktualnych potrzeb jednostki [Armour et al. 2016, 210].

Wnioski z badań psychologicznych dostarczają jednak dowodów, że człowiek w większym stopniu niż na obiektywne dane zwraca uwagę na własne doświadczenia, w tym na efekty zachodzących w życiu zmian. Powyższe oznacza zatem, że poszczególne opcje, przed wyborem których staje jednostka, będą miały niepowtarzalny wymiar uwarunkowany dotychczasowymi indywidualnymi doświadczeniami z niedalekiej przeszłości, przez co rozmyciu ulega ich rzeczywista wymierna wartość postrzegana w sposób czysto obiektywny. Percepcja pozostaje więc w pełni zależna od indywidualnego punktu odniesienia. Jednym ze znanych przykładów przywoływanych zarówno przez psychologów, jak i ekonomistów na udowodnienie powyższej tezy jest tzw. efekt posiadania, czyli teoria, zgodnie z którą wykazujemy tendencję do przypisywania większej wartości dobrom, które już posiadamy oraz w silny sposób odczuwamy negatywne efekty utraty posiadanego już dobra.

Poszukując uzasadnienia dla ludzkiej skłonności do indywidualizacji, również i w tym przypadku wielu odpowiedzi dostarczają badania z zakresu neurobiologii. Na początku XXI wieku naukowcy zainteresowani fenomenem efektu posiadania zaczęli poszukiwać dla niego uzasadnienia o podłożu czysto biologicznym, które miało wypełnić luki dotychczas poczynionych obserwacji psychologiczno-behawioralnych [Cithero, Smith 2009, 1]. Dotychczas największy sukces w tym zakresie przypisuje się De Martino et al., którzy przy użyciu rezonansu magnetycznego po raz pierwszy zdołali nie tylko zaobserwować i przeanalizować aktywność poszczególnych partii ludzkiego mózgu w zakresie tendencji do subiektywnego wartościowania, ale również dostrzegli, w jaki sposób obszary te reagują na występowanie u badanych jednostek indywidualnych preferencji, które nieuchronnie wpływają na procesy wyceny dóbr oraz podejmowania decyzji.

Nauka dostarczyła również dowodów na to, że błędy popełniane w wyniku polegania na indywidualnych doświadczeniach są ściśle powiązane z ograniczonymi możliwościami ludzkiego mózgu w zakresie przetwarzania danych. Następuje więc konieczność polegania na pewnych uogólnieniach, swoistych heurystykach, bez potrzeby każdorazowego sięgania po szczegó- 
łowe dane [Armour 2016, 211]. Co więcej, człowiek, wyciągając wnioski na podstawie zaledwie ułamka dostępnych danych, które jest w stanie zarejestrować w swojej świadomości, nie ma możliwości dokonania zobiektywizowanych i dających się z góry przewidzieć wyborów.

\section{Błędy behawioralne - implikacje dla rynku finansowego}

Przenosząc skutki działania powyższych błędów behawioralnych na realia rynku finansowego, w pierwszej kolejności stwierdzić należy, że efekt dążenia do natychmiastowej gratyfikacji powoduje, że uczestnicy rynku będą zdecydowanie bardziej podatni na te opcje inwestycyjne, które niosą za sobą perspektywę szybkiego zysku. Wskazując jako przykład rynek akcji, przejawia się to w wykazywanej przez inwestorów detalicznych tendencji do inwestowania w papiery wartościowe, które już w momencie zawierania transakcji wykazują powolny, aczkolwiek systematyczny wzrost wartości, gdyż w oczach konsumentów realna staje się wtedy pespektywa wymiernego zysku. Jednakże w przypadku efektywnie funkcjonującego rynku, który w pełny sposób odzwierciedla informacje o rzeczywistej wartości towarów znajdujących się w obiegu, taki rodzaj inwestycji - jako najczęściej i wręcz masowo wybieranej - nie jest w stanie finalnie przynieść oczekiwanego zysku [Barber, Odean, Zhu 2009, 181].

Chęć szybkiego otrzymania środków finansowych przy jednoczesnej możliwości odsunięcia w czasie ponoszenia kosztów podejmowanej działalności miał również wpływ na rozkwit rynku pożyczek krótkoterminowych (tzw. „chwilówek”, paydaylending). Pomimo bowiem powszechnej wiedzy o ich nieproporcjonalnie wysokim oprocentowaniu w porównaniu do innych dostępnych źródeł kredytu, konsumenci niezwykle często sięgają po tego typu pożyczkę, gdyż w ich percepcji na plan pierwszy wysuwa się perspektywa natychmiastowego pozyskania „żywej gotówki”, podczas gdy same koszty pozostają mniej zauważalne jako odsunięte dopiero do momentu spłaty długu w przyszłości [Melzer 2011, 517].

Wiedza o potencjalnym zakłócaniu procesu decyzyjnego przez indywidualne preferencje jednostki wykorzystywana jest z kolei przez firmy inwestycyjne (tzw. sprzedawców, sellers) na etapie zachęcania konsumentów do 
dokonania inwestycji. Okazuje się bowiem, że wpływ własnych doświadczeń na percepcję ludzką powoduje, że inwestorzy najbardziej podatni pozostają na sposób zaprezentowania warunków sprzedaży danego produktu, nie natomiast na jego obiektywną charakterystykę. Instrumenty finansowe należą do grupy specyficznych, aczkolwiek w dalszym ciągu - kontraktów. Jak natomiast w przypadku wszelkich typów umów ich warunki mogą być zmieniane i dopasowywane do potrzeb stron w najdrobniejszych nawet szczegółach. Będąc w posiadaniu środków umożliwiających skuteczną adaptację warunków instrumentów finansowych do potrzeb konsumentów, oferujący osiągają efekt, dzięki któremu nie zrażają (a wręcz przyciągają) do siebie inwestorów wyedukowanych, jednocześnie wypracowując wysokie zyski poprzez zmylenie przeciętnych konsumentów i wykorzystując ich skłonność do „podążania za tłumem". Sprzedawcy jako profesjonalni uczestnicy rynku są w stanie w taki sposób zaprojektować dany produkt, aby uwypuklić w nim cechy najbardziej pożądane przez większość konsumentów (np. cenę). Korzyści dla inwestora w postaci rzekomo niższej ceny są jednakże rekompensowane przez firmy inwestycyjne poprzez wprowadzanie dodatkowych ryzykownych z perspektywy klienta warunków sprzedaży danego instrumentu finansowego, przy czym sposób ich zaprezentowania konsumentowi ma spowodować, iż w praktyce dla przeciętnej osoby nieznającej realiów inwestycyjnych pozostaną one niewidoczne. W takim scenariuszu wyedukowani inwestorzy - będąc w pełni świadomi praktyk stosowanych przez sprzedawców - decydują się jednak na podjęcie ryzyka w postaci zakupu najkorzystniejszych cenowo produktów, jednocześnie będąc w stanie zabezpieczyć swoje interesy poprzez $\mathrm{m}$. in. dywersyfikację portfela. Pozostała grupa inwestorów „na ślepo" podąża za nimi, postrzegając dany produkt jako bezpieczny, nie mając wiedzy i doświadczenia w zakresie dodatkowego zabezpieczenia źródeł finansowania.

\section{Wnioski i perspektywy regulacyjne - czy istnieje „złoty środek”?}

Identyfikacja tendencyjnych zachowań ludzkich ingerujących w niezakłócony proces podejmowania decyzji, a także naukowe wyjaśnienie ich podstaw biologicznych pozwalają na wysunięcie wniosku, iż w rzeczywistości 
niepoprawne jest dalsze posługiwanie się sformułowaniem „błędów behawioralnych". Analizowane postawy i zachowania posiadają bowiem ewolucyjne zakorzenienie w ludzkim mózgu, w związku z czym ich występowanie z mniejszym lub większym natężeniem - należy uznać za naturalny czynnik stanowiący nieodzowną część wszelkich działań podejmowanych przez człowieka. Wnioski formułowane przez neurobiologów prowadzą do konstatacji, że zamiast podejmować z góry skazaną na niepowodzenie swoistą walkę z ludzkim umysłem, prawdziwym wyzwaniem dla regulatorów powinno być stworzenie optymalnych warunków, w których skutki popełnianych błędów zostałyby w jak największym stopniu zneutralizowane. Chodzi więc o stworzenie przyjaznego środowiska dla inwestorów detalicznych, w którym pozostawia im się jak największą swobodę wyboru, lecz jednocześnie asekuruje poprzez implementację odpowiednich mechanizmów ochronnych.

Prawodawca ma do dyspozycji dwie główne grupy narzędzi regulacyjnych, z których pierwsza nakierowana jest bezpośrednio na konsumentów, a druga - na szeroko rozumiany rynek. W ramach pierwszej grupy wyróżnić można mechanizmy ograniczające dostęp inwestorów detalicznych do niektórych obszarów rynku, uważanych powszechnie za obarczone wysokim ryzykiem nieproporcjonalnym do standardowych potrzeb inwestorów indywidualnych. Regulacja samego rynku może natomiast przede wszystkim skoncentrować się na wprowadzeniu norm prawnych nakierowanych na działalność firm inwestycyjnych - nakładania obowiązków informacyjnych czy regulowania relacji "firma-klient” [Moloney 2010, 53]. Niezwykle ciekawa jest również proponowana przez Bar-Gill i Warren koncepcja regulowania rynku od strony przedmiotowej, tj. wprowadzenia szczegółowych regulacji odnoszących się do instrumentów finansowych oferowanych konsumentom, które - podobnie jak ma to miejsce w przypadku rzeczy ruchomych oraz produktów niebezpiecznych - powinny spełniać określone standardy i normy jakości.

Już sama pobieżna analiza kluczowych aktów prawnych z zakresu rynku kapitałowego, takich jak MiFID II czy UCITS V, pozwala na spostrzeżenie, że jest to w zasadzie unikatowy konglomerat wszystkich wymienionych powyżej dostępnych mechanizmów regulacyjnych. Pozornie stan ten wydaje się paradoksalny; skoro bowiem psychologia dostarcza obserwacji o istnieniu 
typowych dla inwestorów błędów behawioralnych, a neurobiologia jest w stanie uzasadnić naukowo mechanizmy odpowiedzialne za ich występowanie, to powinniśmy być już zaledwie o krok od znalezienia regulacji „złotego środka".

Na zakończenie można więc postawić następujące pytanie: dlatego w dalszym ciągu prawodawca nie może osiągnąć celu w postaci stworzenia regulacji doskonałej? Odpowiedzi po raz kolejny dostarcza nauka. Neurobiolodzy są co prawda w stanie zaobserwować poszczególne procesy zachodzące w ludzkim mózgu. Jednakże wytłumaczenie, dlaczego one zachodzą, pozostaje $w$ dalszym ciągu zagadką.

\section{Bibliografia}

Armour J., Awrey D., Davies P., Enriques L., Gordon J., Mayer C., Payne J., Principles of Financial Regulation, Oxford University Press, 2016.

Bar-Gill O., Warren E., MakingCreditSafer, "University of Pennsylvania Law Review", Vol. 157, 2008.

Barber B.M., Odean T., Zhu N., Do Retail TradesMoveMarkets?, "Journal of Financial Markets" 2009, Vol. 12, 547-569.

Clithero J.A., Smith D.V., Reference and Preference: How does the Brain ScaleSubjective Value?, Front Hum Neurosci. 2009; 3: 11 (online).

De Martino B., Kumaran D., Holt B., Dolan R.J., The Neurobiology of ReferenceDependent Value Computation, "The Journal of Neuroscience" 2009, 29 (12) 38333842.

Kahneman D., Knetsch J.L., Thaler R.H., ExperimentalTests of the EndowmentEffect and the CoaseTheorem, "Journal of PoliticalEconomy" 1990, Vol. 98, No. 6, 13251348.

McClure S.M., Ericson K.M., Laibson D.I., Loewenstein G., Cohen J.D., Time Discounting for PrimaryRewards, "The Journal of Neuroscience" 2007, 27(21): 5796-5804.

Melzer B.T., The Real Costs of Credit Access: Evidence from the PaydayLending Market, "The QuarterlyJournal of Economics" 2011, Vol. 126, 517-555.

Moloney N., How to ProtectInvestors: Lessons from the EC and the UK, Cambridge University Press 2010.

Glimcher P.W., Rustichini A., Neuroeconomics: the consilience of brain and decision, "Science" 2004, 306(5695):447-452. 
Harris C., Laibson D.I., InstantaneousGratification, "QuaterlyJournal of Economics" 2013, 128(1):205-248.

Lo A.W., AdaptiveMarkets: Financial Evolutionat the Speed of Thought, PrincetonUniversity Press, 2017.

Laibson D., GoldenEggs and HyperbolicDiscounting, "The QuarterlyJournal of Economics", Volume 112, 1997, s. 443-478.

Wilkinson N., AnIntroduction to BehaviouralEconomics, Macmillan, 2017. 